\title{
Career Transitions
}

\section{Theological Librarians and Moves to Academic Libraries in Public Tertiary Schools}

Beth M. Sheppard, University of West Georgia https://orcid.org/0000-0003-3110-9343

ABSTRACT The issue of transitioning from work in theological libraries to public university libraries is explored using the method of autoethnography. Key differences between public, private, and for-profit schools are highlighted and linked to how each type is driven variously by a mission, mandate, or method. Since the ease by which job seekers may adjust when moving between each type may be affected by factors beyond personal preferences for benefits, this paper surveys literature related to fit and retention in the academy; religious privilege; religion and legal doctrine; and faith in the context of secular employment. Finally, the terms theological librarian, religious librarian, and religion librarian are defined relative to the different roles librarians undertake in private versus public institutions. A rubric for evaluating a move to a new employment setting is included as an appendix.

How smooth are career transitions for librarians who are contemplating shifting from a theological library setting in a religiously related institution to working in a public college or university library? In order to explore this question, it is necessary first to tease out the differences between the major types of tertiary educational institutions in the United States and then borrow a method from the social sciences known as autoethnography to further highlight some of their unique characteristics. In autoethnography "a researcher recounts a story of his or her own personal experience, coupled with an ethnographic analysis of the cultural context and implications of that experience" (Lapadat 2017, 589). Given that this paper is designed for presentation at one of the "Listen and Learn" sessions at the annual conference of Atla, sharing personal experiences seems appropriate. So too does indulging in a bit of theological reflection, which will occur near the end of the piece. As for the analysis proper, this will take the form of a literature review. For librarians like us, using a literature review to understand primary issues in a subject 
is as natural as breathing. It turns out that it is also a key means used by ethnographers to interpret experiences and gain insight into the values and conventions of a culture (Ellis and Adams 2011).

Given our central focus, I will share anecdotes of my own transition from a career directing theological libraries in church-related private tertiary education settings, to serving as a tenured full-professor librarian at the University of West Georgia's Ingram Library (UWG), a public institution that is part of the University System of Georgia. As for the literature review, topics include, amongst others, fit/retention in academic jobs as well as religious privilege. Incidentally, while undertaking my research for this project, I began jotting down a list of things that theological librarians might wish to have in mind before going out on a job search. It has developed into a rudimentary "Career Move Assessment Tool." In the hopes that it may prove helpful to others, readers may find that document in the Appendix at the end of this article.

\section{Anecdote 1: The Rocky Interview}

I wanted to move closer to my husband since we'd been in a longdistance commuter marriage (multiple states away). So, I interviewed at a public university where we would have a shorter four-hour commute. Although I had been in a seminary library, I had some of my degrees from public universities and had experience teaching purely academic religious courses stripped of a confessional point of view. I could make this sort of career change! For the interview job-talk, I scoured my presentation to ensure there wasn't anything that even mentioned religion. It focused exclusively on digitization, repositories, and future possibilities for technology in libraries. I was confident I had this "church/secular school" thing figured out and scrubbed out. I was wrong. During the question session, one member of the audience, who had access to my resume and knew I had been a theological librarian, exclaimed, "You don't fit here! What is to keep you from trying to convert us?" Given that reaction, I was ready to pack up and head home from the interview. But the visit host convinced me this individual was an anomaly. When I ultimately landed the job, I learned the host was wrong. It was a fear also held by others. 


\section{METHODICAL CONSIDERATIONS AND REASON FOR STUDY}

To be sure, there are some benefits related to using the method of autoethnography besides serving as a vehicle to share personal experiences with colleagues in a structured conference setting. For instance, as Judith Lapadat points out, in focusing on one's own story, the researcher avoids the pitfall of appropriating the voices of others and clearly eschews false claims of objectivity. Yet, she notes that there are also dangers. Notably, autoethnography is an exercise in which there is no distance between subject and researcher. Furthermore, the use of autobiography could cause the work to easily slip into narcissism (Lapadat 2017, 589, 591, 596). A more subtle difficulty assailing those using this method is the critique that the autobiographical sketches that appear often demonstrate inadequate literary and stylistic mastery of that genre (Ellis and Adams 2011). I make no claims that the episodes I recount during this study are great literature. Rather, my goal is to share a few incidents that I believe may resonate with others who either have already made career shifts between private and public academic libraries or may someday find themselves undertaking such a move. First, though, I do want to acknowledge that there are a wide range of motives for making career changes.

Sometimes moves, like the one from which my own anecdotes are drawn, are made for personal and professional reasons such as to be closer to family, find a better school system for one's children, cut down on a long commute, earn a larger salary, or even have better opportunities for advancement. Beyond considerations like these, however, there are very real forces at play in the United States that may mean that opportunities to serve as a theological librarian in the United States will eventually be hard to come by. As a result, opportunities in the public sector may seem attractive to several of the members of our association. Hopefully, then, this study will both be timely and serve as a helpful resource.

The forecast of an eventual tightening of the job market in our librarianship specialty is based on two data points, one drawn from Gallup and the other the Association of Theological Schools (ATS). First, according to Gallup polling, the US population seems to be drifting away from religious affiliation. While in $199970 \%$ of Americans indicated they were affiliated with a house of worship, by 2020, a mere decade later, only 47\% made that same claim (Jones 2021). No doubt this trend toward a secular society will be similar to that in 
areas of Germany where it may now be said, "religion has hardly played any role" for generations (Schröder 2017, 28). One would surmise that a population's drift away from formal worship would have a knock-on effect in terms of the number of theological libraries that will be needed to support the training of a dwindling number of religious leaders.

The second set of statistics, provided by the Association of Theological Schools (ATS), helps to make the case that retrenchment related to library employment in theological contexts is not necessarily hypothetical, but already in motion. According to ATS data, the number of librarians in member schools was down 7\% in 2020 over the number reported in 2016 (ATS, Tables 3.9A, years 2016-17 and 2020-21). ${ }^{1}$ The ironic point about this ATS number is that the membership in that organization has increased over the five-year span, moving from 247 schools to 258 . This makes the drop from 337 librarians to 313 even more significant—an average decrease from 1.36 positions per school in 2016-17 to 1.21 per school in 2020. ${ }^{2}$ Presumably shared libraries, online collections that require fewer librarians than do those that are print for curation, and other efficiencies are at play. ${ }^{3}$

\section{THE THREE TYPES OF ACADEMIC INSTITUTIONS}

One might think that transitioning to a library in a state school from a position in a theological library or one in a private university would be seamless. After all, there they have the common educational requirement of a master's degree in library science and shared concerns for promoting information literacy. Also, many software systems, platforms, and vendors are ubiquitous across all types of libraries. This assumption, however, may not prove true for every employee. Because schools may be quite different from one another in terms of cultures and objectives either limited to or beyond degree completion, adjusting to the new employment setting may take some time.

\section{Anecdote 2: The Gut Punch Graduation}

Upon arriving on campus at the public university July 1, one of my first duties was to process during the summer graduation ceremony. The act of donning regalia in a robing room was familiar; so was marching with colleagues of my same rank to the usual brass-heavy processional music. Upon reaching the front of the arena, I was 
momentarily startled because I couldn't find the crucifer holding a cross. I was accustomed to acknowledging it before ascending the dais and finding my seat. Nor was there a prayer at the beginning of the ceremony. Intellectually I knew these things would not be present at a secular, public institution. I didn't expect them to be. But it wasn't until that moment, when I was caught up in habits long formed, that I realized how accustomed I was to these small religious observances, how terribly I would miss them, and how much I had taken them for granted in my previous role as a theological librarian at a seminary.

Tertiary educational institutions may be classified variously by degree levels, amount of research conducted for sponsoring bodies, length of program, size of their student population and other criteria. There are also three very distinct types of sponsorship or control for institutions in the United States: private, public, and for-profit and even though we are primarily concerned with the first two, sketching out the differences between all three will provide a clearer picture of the US educational landscape.

Oddly, the issue of institutional control is so fundamental to an organization's identity, that it may be taken for granted in discussions of how institutions might be compartmentalized. For instance, Alexander McCormick and Chun-Mei Zhao provided commentary on the major revision of the Carnegie Classification system that occurred a decade and a half ago (2005). They discussed many of the categories that remained the same and those that were modified or were new, but didn't specifically mention control (2005). ${ }^{4}$ Yet, the centrality of whether an institution is private, public, or non-profit is implied in the fact that in addition to a school's name and location, it is one of the key pieces of information that appears in the educational institution "look-up" directory on the Carnegie website.

Although for-profit educational institutions began a period of accelerated growth at the end of the twentieth century, post-secondary for-profit degree-granting schools served only about $5 \%$ of total postsecondary enrollment in 2017-18 (de Brey et al. 2021, 46). By contrast, the 2018 classification summary data table provided by Carnegie indicates that in the United States there were 1,665 public schools serving $14,722,505$ students and another 1,743 private schools with an enrollment of 4,254,414. ${ }^{5}$ Within this number of privates, the basic Carnegie categorization does not disaggregate the number of doctoral and master's degree-granting schools that are associated with religious bodies. The exception involves four-year 
colleges, which may elect to carry the designation "faith-based." It so happens that in 2018 three hundred had this label. Together these faith-based four-year undergraduate schools enrolled a subset of 88,068 of the four and a quarter million students educated at private institutions.

When it comes to the issue of control, there are tensions that exist between how private, public, and for-profit schools go about the business of education. This is sometimes expressed in stereotypes. For instance, Samuel Schuman recounts a story about faculty members at a public university voicing reluctance to join a new athletic conference that just happened to include several churchrelated schools. They were concerned that playing against "two-bit Bible colleges" would somehow lessen the public school's prestige. Schuman describes the insult used by his colleagues as "a truly distasteful example of the least enlightened view of religious colleges and universities sometimes entertained by otherwise clever academics in the secular sphere" (Schuman 2010,4).

\section{Key Ends of Private, Public, and For-Profit Schools}

Encountering a negative stereotype like that may be disconcerting to individuals who have dedicated themselves to a career in theological education. Indeed, for some members of Atla, theological librarianship is a ministry to which one may be called (Morris 1953/2006; Keck 1996; Peterson 2001; McMahon 2010; Shaffett 2013; Campbell and Keck 2020), and working at a faith-based school at the tertiary level is a noble pursuit. Stereotypes aside, what are the differences between public institutions and private schools that have a religious orientation? As Jessica Mann puts it, the latter are open to integrating "faith, learning, and living in a way that holistically develops students while simultaneously working toward the common good" (Mann $2020,8)$. This is not to say they are cookie-cutter representations of each other. Rather, there are areas of individuation and distinctives in each organization. Further, some are formerly religious, and an inclination to accept a religious disposition amongst some stakeholders may be all that remains of a religiosity that is otherwise "historical or nominal." When it comes to instruction and the formation of students, religiously related schools reflect the unique theologies of their sponsoring religious group-as well as the resultant anthropologies that play out in instructional pedagogy, curriculum, student life, and other elements of the educational experience (Liftin 2004, 13). 
For their part, public schools are more limited in their objectives. They are not concerned with formation but are focused primarily on conveying disciplinary knowledge with the additional goals of educating for citizenship, strengthening social cohesion, and benefiting the public good (Calhoun 2011, 3-4). The public good may be narrowly understood as the set of specific interests of the state that funds the school's budget, or in a more general sense, such as the ideal of providing greater access to education than is available via the private schools. Indeed, since a private school's range of impact is limited by their being funded primarily by euergetism and tuition fees, public schools help to meet market demand. ${ }^{6}$

For-profit colleges and universities, at least many of the ones developed in the latter part of the twentieth century, have another set of aims and objectives that diverge from those of the publics and non-profit privates; they financialize credits for the gain of shareholders. Another difference is that while publics and privates are legally required to serve the public good as a function of their nonprofit status, the market-focused schools are not (Fox-Garrity 2017, 13). This may appear to be an unfair advantage for the for-profits. After all, although revenue is primarily from student tuition, a significant part of that may be generated through Title IV financial aid which is portable and accompanies financially disadvantaged students (Fox-Garrity, 14). In essence, their work is being subsidized by federal tax funds.

\section{Mission, Motive, and Mandate}

Another scheme for describing the three major types of control is based on work by J. A. Sheppard and uses the terms "mission," "mandate," or "motive" as laid out in Table 1 (Sheppard 2011). ${ }^{7}$ Since control has a direct impact on organizational ends and thus influences an institution's culture, this mode of thinking about colleges and universities might prove helpful to theological librarians considering a career move attempting to judge how different another school might be from their current employer. 
TABLE 1: Characteristics of Institutions by Control*

\begin{tabular}{|c|c|c|}
\hline Mission-Driven (Private) & Mandate-Driven (Public) & Profit-Driven (For-Profit) \\
\hline \multicolumn{3}{|l|}{ Focus } \\
\hline $\begin{array}{l}\text { Formation of students or con- } \\
\text { ducting research that supports } \\
\text { ultimate mission of founder/ } \\
\text { founding group. }\end{array}$ & $\begin{array}{l}\text { Earning of degrees or completion } \\
\text { of research for its own sake or for } \\
\text { the common good. }\end{array}$ & $\begin{array}{l}\text { Increased market share for } \\
\text { greater profitability. }\end{array}$ \\
\hline \multicolumn{3}{|l|}{ Distinguishing Funding Source } \\
\hline Charitable donations. & $\begin{array}{l}\text { Taxpayer funds allocated through } \\
\text { state budgeting process. }\end{array}$ & $\begin{array}{l}\text { Initially investment from stock- } \\
\text { holders; then student tuition. }\end{array}$ \\
\hline \multicolumn{3}{|l|}{ Faculty/Staff } \\
\hline Educators. & Civil Servants. & Corporate Employees. \\
\hline \multicolumn{3}{|l|}{ Community } \\
\hline $\begin{array}{l}\text { Belonging, hospitality, and col- } \\
\text { legiality are celebrated. }\end{array}$ & $\begin{array}{l}\text { Community is possible, but not } \\
\text { necessary for completing the task. }\end{array}$ & $\begin{array}{l}\text { Fast paced, target-focused, } \\
\text { sales-oriented work environment. } \\
\text { Competition may be encouraged. }\end{array}$ \\
\hline \multicolumn{3}{|l|}{ Values } \\
\hline $\begin{array}{l}\text { Common set of values upheld } \\
\text { and encouraged in addition to } \\
\text { educational content. }\end{array}$ & $\begin{array}{l}\text { Ensuring students graduate and } \\
\text { grant dollars are obtained is } \\
\text { valued by institution. } \\
\text { Avoids privileging one set of } \\
\text { citizens and their values over oth- } \\
\text { ers within students' educational } \\
\text { experience. }\end{array}$ & $\begin{array}{l}\text { Efficiency and acquisition of } \\
\text { students at lowest cost are valued } \\
\text { by institution. }\end{array}$ \\
\hline
\end{tabular}

Let's unpack some of the key elements from the table. Private schools are depicted in the table as mission-driven. That is to say, they were established as a special assignment by their founders with an eye toward forming students. This plays out in whether the employees-be they administration, faculty, or staff-may feel compelled or called to work in response to a higher power, ideal, or set of values. A Christian school that focuses on promoting justice in service to the Kingdom of God would be an example of a missiondriven institution. Strictly speaking, such a school would be ultimately accountable to God for the quality of its programming and faithfulness to its mission-though this control by the divine may be represented by the oversight of representatives from the particular faith tradition with which the school is associated. Private donations 
by those who hold the same values as the founders, laity who belong to the faith tradition, or perhaps the denomination/religious body itself are contributed to help support these types of schools in their mission. These funds are joined with other revenue streams such as tuition, endowment earnings, revenue from auxiliary enterprises (for instance, from a food service provider), and external sources of student financial aid to make up annual budgets.

By contrast, public institutions operate under a mandate. In short, the will of the people determines (mandates) that the citizenry be educated. In support of this self-imposed obligation, the residents of the state pay taxes that serve as the primary source of funding for the school. For their part, educators are employed without regard to a set of higher values, but simply because they possess the basic credentials and skills to demonstrate command of their respective subjects. Ultimately, those working at public schools are responsible to the taxpayers as represented by the governor and legislature.

The last category is that of the for-profits, which are described as having a motive. The goal in establishing a school with this status is to make money for the investors/shareholders, as represented by the board of directors. While publics and non-profits are constrained by nondistribution rules and must put all excess funds generated back into the goods and services they were designed to provide, for-profits are not hindered in the same way (Fox-Garrity, 16). As a result, their boards are motivated to encourage as school's leadership to increase market share and control expenses-all with an eye toward generating excess revenue to be paid out to investors (Fox-Garrity, 18). Thus, for-profit faculty, just as is the case of the publics, are hired because they hold proper credentials. They must, however, also be capable of meeting specific goals and metrics in a fast-paced, high-volume environment designed to help the school maintain profitability. Granted, these schools may still serve the public good, or even have distinctives that seem to echo some of the values of private schools, but these are incidental.

To be sure, the characteristics that appear in the table and mentioned above represent some generalizations. Not every school of a given type will embody each of the characteristics consistently. Changes in administration, institutional culture, legislation, and other factors mean that a school of one type may, at least for a while, appear like one from another type. 


\section{Anecdote 3: Where Are the Refreshments?}

During my first few months of employment at UWG I discovered that a penchant for holding a myriad of meetings seemed to be a highereducation universal. However, there were never any refreshments. In my previous experience in private higher ed, "table fellowship" was considered a means of building community and we rarely gathered without at least coffee available. Concerned that UWG had fallen on hard financial times, I asked whether budget struggles were the reason why food was missing. I was told that taxpayers paid us to teach; they didn't buy us groceries too. About two years after this conversation, a new president took the helm. He sent around an invitation for everyone to attend his first Presidential Address. Surprisingly, the letter of invitation let us know that refreshments would be provided specifically "to foster a sense of belonging and connectedness" (Kelly 2021).

The three types of institutions, however, are likely to remain true to form in the long run; therefore, a librarian seeking to transition from one sector of higher education to another might wish to keep this in mind. Regardless, the fact that there are three distinct raisons d'être associated with schools in the United States' educational landscape is to be celebrated. The variety in the system differs from the models in other countries, such as those that have a single centralized system under government control, or a set nationwide curriculum. The variety in the United States, combined with US educational institutions' ability to respond to change and market forces as they see fit, means that higher education has had a positive outcome. Specifically, education is widely accessible to the US population. In fact, over $50 \%$ of the population between the ages of 18 and 25 have a tertiary degree or at least have attended some college (US Census Bureau 2019). Furthermore, tertiary degree attainment by those 25-34 in the US exceeds the average of the Organization for Economic Co-operation and Development member nations (OECD 2020).

\section{Other Differences in Academic Institutions}

In a few moments we will look at relevant literature for providing context for some of the anecdotes listed above. Before doing so, it is important briefly to acknowledge some other factors that may play into a theological librarian's deliberations about making the leap to a position in a secular environment. For instance, whether a campus is rural, urban, or distributed (with most work accomplished remotely) may be a personal preference. For their part, Clery Act statistics 
are worth investigating as part of one's decision-making process since they are an indication of campus safety. In addition, a school's financial stability may impact one's ability to adjust to a new job. To be sure, some institutions are well-endowed by private donations or receive generous taxpayer funding, while others are financially distressed. It is good to know in advance whether a school is prone to issuing late paychecks or conversely, in a position to offer generous retirement plans and perks like no-cost loans for housing. One final difference to note is that just as faith-based schools may be alternately conservative or liberal theologically, public schools may have distinct political leanings driven by their need to lobby for funds in their state capitals. Further, schools dependent on the budgeting process of state governments will alternately shed or assume the dominant political ideology of the state's current leadership.

\section{Anecdote 4: Achoo!}

During the pandemic, mask-wearing at UWG was dependent on cues from the Republican governor. So, it was no surprise that during the summer graduation ceremony, the stage party was unmasked. Although fully vaccinated, my religious convictions drove me to wear one to be considerate of others' health and wellbeing. More than one person attending the event, however, gave me the sideeye. In the end, I was relieved to have my mask, given that the Delta Variant was on an upswing and the individual seated next to me sneezed throughout the entire event. I just pray that the unmasked graduates in front of my sniffling, wheezing seatmate didn't end up catching the virus.

Along with the factors just mentioned, when changing jobs, it is also helpful to be attuned to the school's reputation. Some are proud of being prestigious research institutions, others are noted for their sports prowess, still another group may be humble and completely unknown beyond a short radius of their main campus. Another consideration beyond the basic campus culture that is worth weighing is whether the school offers faculty status to librarians. While some may find the security of tenure comforting, others who are hired pre-tenure may regard the stress and uncertainty associated with the preparation of a portfolio and subjecting one's scholarship and performance evaluations to peers during the review process to be worth skipping. It seems that if one is seeking employment at a school that has membership in the Association of Research Librar- 
ies, there is about a $54.8 \%$ probability of ending up in a position that leads to tenure (Antell and Hahn 2020, 8).

Finally, it is also important for the job seeker to be willing to work with the primary population served by the institution. Some schools, for example, may be celebrated for the work they do as second chance schools. Others serve adult learners. A few focus on educating specific racial/ethnic groups as is the case with HBCUs or Tribal Schools. Some educate at the graduate or professional level, while others pride themselves on their programs for undergraduates. Regardless, a theological librarian's knowledge base, passions, and experience may position one to thrive in some of these environments more readily than in others. Many of these factors are included in the Career Move Assessment Tool found in the appendix and may be weighted in accordance with personal preferences.

I do want to take a moment to share some less obvious differences that I myself perceived in the transition from a private sector to UWG since they were items that I had not even thought to bring up during my interview. They may prove helpful for others to consider. First, UWG functions like a branch campus of the "system" rather than a standalone university. This plays out in a variety of ways. For instance, my paycheck is from the system, not UWG. This has a positive effect in that I am a state employee and can take part in the state pension plan. Being a state employee in a system, though, can be a bit of a mixed bag in terms of school policy and budget. As was illustrated in Anecdote 4, for instance, many decisions are made at the system level in Atlanta, not locally at UWG. While neither positive or negative in and of itself, it is important to note that with this extra level of bureaucracy, sometimes decisions take longer than they might at a standalone school. It is important to have realistic expectations about the pace at which an institution's administration can move. Finally, responsibility to the taxpayer at UWG plays out in a variety of ways that might make one uncomfortable. To be specific, should the state revenues or even our campus revenues go sour, all employees at UWG may be asked to take furloughs. These are days when we would be directed not to come to work, and we would not be paid for those days. In addition, Georgia is an open-records state. This means that all salaries are published in a publicly accessible database. This openness even extends to employee emails (despite standard clauses in the email signature block about messages being limited to their intended recipients). As I understand it, every 
message sent or received using school email accounts is archived and available to the pubic upon request under certain conditions-a marked difference from some seminary environments where clergy faculty members may use email to conduct pastoral conversations with the presumption of a fair degree of confidentiality. These sorts of policies may vary from school to school, and it is worth having one's eyes wide open about them before taking a job.

\section{LITERATURE REVIEW}

Rather than relying purely on a single person's subjective experiences about a career transition, it is important to explore what others are saying about religion and life in the academy.

There are four topics in the academic literature that are relevant. They are 1) fit and retention of employees in academic settings, 2) the phenomenon of religious privilege in higher ed, 3) the extent religion in the public sphere, including public tertiary education may (or may not) be subject to legal protections, and 4) how one lives out one's faith in the context of secular employment. Given time limits for this presentation, just a few articles are highlighted to give a sense of the relevant issues.

\section{Fit and Retention in the Academy}

Although it is possible to talk about "fit" when it comes to matching job candidates with openings, it turns out that it is a concept that is "amorphous and poorly articulated" (White-Lewis 2020, 2). In theory, a good "fit" occurs when the job seeker feels attachment to an organization. Damani K. White-Lewis points out that scholarship on the topic of fit identifies two types, one of which is a bit more concrete than the other. Search committees appear to be on firmer ground with what is known as person-job fit. This type of match involves evaluating a candidate's skills, knowledge, and ability. It is determined at early stages in the search process, and there is often some consensus amongst search committee members about each candidate's degree of success in meeting these basic position requirements (White-Lewis 2020,13). By contrast, the second type of fit, known as person-organization fit, seeks to discern alignment between values and identity. Assessing this sort of match is more idiosyncratic because committee members tend to use their own perceptions rather than a set of specific criteria. In fact, White-Lewis warns 
that without a rubric, this is the point in a search where cultural and racial biases may come into play $(2020,4)$. Given that search processes in the academy may lack an objective basis for personorganization fit, job seekers should neither take failure to land a position too personally nor feel inadequate but should remain positive instead. Furthermore, job contenders would be wise to develop measures for a desirable match of their own before engaging in the job hunt. To this end, the Career Move Assessment Tool that is appended to this paper functions as a model of the type of rubric that might be applied consistently across several potential positions.

Ultimately, whether a given fit is successful is determined by a school's ability to retain faculty and staff employees. The literature on that topic mentions a few perks beyond salary and basic benefits that sometimes have a bearing on their job satisfaction. These include the availability of funding for advanced degrees, fair and clear processes for tenure and promotion, the availability of mentorships, and the ability to work according to flexible schedules (Harris 2019). ${ }^{8}$ Sometimes, the availability of parental leave benefits may also have a bearing on retention (Rupp 2018). Finally, whether a tertiary school's basic administrative policies and procedures may align with employee values may alternately contribute to loyalty or conversely lead to disenchantment. Along these lines, Kerry O'Meara pointed out that one school's insistence on employees obtaining outside offers of employment for positions they did not plan on accepting before being granted raises by their current school was viewed by some employees as unethical. Ultimately, O'Meara contends, this policy led to resentment and contributed to talented faculty trickling away to competing universities (O’Meara 2015, 293).

Although it may not be on one's radar during the interview, a school's orientation process for new hires also has an impact on how successfully one assimilates into a new work culture. Indeed, some prospective employees prefer being thrown into the deep end, while others benefit from a structured onboarding program. It is during orientation that new employees seek information about things like an institution's values, the degree to which the organization fosters a sense of community, and its commitment to fostering work-life balance (Scott, Lemus et al. 2016, 15). Now that we mention it, a job aspirant might want to gain some insight into these elements during the search process instead of waiting for them to be revealed during orientation. 
When it comes to the role that faith plays in fit and the work environment, two studies are of interest. First, Fanny Rantung (2014) developed a questionnaire to determine the satisfaction level of faculty members at four religiously affiliated schools in East Indonesia. Her survey was compiled after visiting with faculty focus groups and included points like whether faculty members were happy with the levels of their travel and book allowance (incidentally, these are two additional factors that those seeking to switch employers may wish to include in hiring negotiations). The surprising feature about Rantung's questionnaire was that there were no questions related to religion or calling, though one question did appear related to “moral values” (Rantung 2014, 57). This lack was notable given that the four schools involved variously represented Catholic, Protestant, and Muslim affiliations. ${ }^{9}$ Presumably employees were in harmony with the degree of religious praxis on their respective campuses and willingly conformed to any faith-driven policies that were in place. Otherwise, issues related to religious culture likely would have arisen as a point of concern in the focus groups upon which the survey was based.

In another study, Kristen Edwards (2015) discovered that employees in Historically Black Colleges and Universities where Christian faith traditions play a significant role, were aware of the institutions' religious identity and valued it. Black women faculty appreciated the Christian emphasis and described their work as taking place within a community that provided solace and support in a world where their gender and race might otherwise put them at a disadvantage. Edwards did question whether the religious identity of such institutions would become problematic for students whose aptitudes and self-concepts might not align with the environment of the school in instances where HBCUs were being pressured to admit ever more diverse populations (Edwards 2015, 264).

Given these two studies, it appears faith-based institutions that deliver tertiary education are often successful in creating a campus environment that reflects the values and ideals of the sponsoring religious bodies. Since sometimes a college or university's culture may diverge from that of the mores and behaviors of society at large, theological librarians should carefully weigh the degree to which they are comfortable functioning either within or outside of a community organized in accordance with a particular religious ideology or mission. 


\section{Religious Privilege}

In order to fulfill any aspects of their missions related to these religious ideals, faith-based schools may provide curricula in which sacred texts or religious precepts are taught, time in daily schedules set aside of worship, semester breaks appear on calendars in ways that accommodate holy days, spaces for religious observance and purification rituals are available, food services are designed to cater to the dietary requirements of the faith, clergy or spiritual directors are present to assist students in their faith journeys, religious artwork and symbols appear in campus architecture or even on letterhead or branding materials, and so forth. Theological librarians who are fulfilled working within a microculture where a particular faith is advantaged in this way should carefully consider the degree to which the culture of a secular, public university campus may differ. Since Christianity has been the dominant religion in the United States since the founding of the country and is culturally pervasive in the country, literature on a phenomenon known as Christian privilege may prove enlightening. ${ }^{10}$

\section{Anecdote 5: Winter Celebration}

As December approached, planning for the faculty/staff social gathering began. Because the event is held at a time when several religions celebrate holidays, the goal was to create a secular, yet welcoming atmosphere. One year, however, poinsettias were selected as table centerpieces, not knowing the flowers were associated with Christianity. Colleagues of other faiths and those who were atheists were vociferous in their objections to the choice. The reactions were so strong, in fact, that since the fateful misstep, the tables are bare, and no one dares risking the words "holiday" or "seasonal" relative to the event.

In the main, Christian privilege as described in the United States is “...a seemingly invisible, unearned, and largely unacknowledged array of benefits afforded to Christians," a phenomenon that has the unfortunate byproduct of "subordinating members of other faiths as well as non-believers" to a Christian worldview and practices (Fairchild and Blumenfeld 2007,177). Examples of the type of advantages Christians enjoy include the expectation that one may display a "Jesus is Lord" bumper sticker on a car without worrying about it leading to the vehicle being vandalized or the general assumption that leaders and elected officials are likely Christian (Clark, Vargast et al. 2002, 54). 
There are two models that seek to counterbalance some of the more oppressive aspects of Christian privilege for those of other faiths. The first is multiculturalism. In this scheme, various traditions and non-believers are welcomed. All exist side by side in a culture of mutual respect and toleration (Bowman and Smedley 2013, 746). ${ }^{11}$ The second model is that of pure secularism. In this way of constructing work and learning environments, the objective is to ensure individuals' and groups' “freedom from” religion as well as "freedom of" religion by either stripping religion completely away or taking care not to impose one's traditions and values on others (Blumenfeld 2005, 208).

For those accustomed to working in a college or university environment where a dominant faith tradition is intentionally cultivated in service to the school's mission, adjusting to a setting where that particular faith may no longer have a privileged status may be difficult. In the case of Christianity, this is sometimes related to the perception that there is anti-Christian bias on campus (Lee 2021). In such an environment, Christian academics may feel pressured to hide their faith (Haggerty 2010) or may be hypervigilant about displaying behavior that could be interpreted as intrusive, proselytizing, or overly conservative (Edwards 2015, 271).

\section{Religion, Government Employees, and Legal Doctrine}

Closely related to the extent to which religion should be visible on public campuses is the issue of religious freedom. When it comes to being a government employee within public colleges and universities, uncertainty about one's ability to object to performing assigned tasks based on religion, or to demonstrate an individual expression of religiosity such as wearing religious symbols or garb, is par for the course. In fact, legal doctrine with respect to the religion of government employees is not well developed. As recently as 2017, Caroline Corbin, a professor of law at the University of Miami, suggested filling the gap in legal literature about such matters by making an analogy with how speech doctrine relates to government employees given that speech doctrine is more robust. Corbin writes that when it comes to free speech, "government employees are not protected from their government-employer to the same extent they are protected from their government-sovereign. In other words, the government may discipline its employees for their speech in a way it cannot punish regular citizens" (Corbin 2017, 1198). If, by analogy, the same 
limits also apply to religion, then the main recourse government employees would have to religious protection wouldn't fall under the First Amendment, but rather laws against discrimination as defined by Title VII of the Civil Rights Act (Corbin 2017, 1250). Given that at present I am not a legal researcher and was able to discover little on this topic besides the rather complex legal piece written by Corbin, I am uncertain of the degree to which this issue may be important for theological librarians entering public school employment. Much more research needs to be done on the issue, though it did seem worth mentioning.

\section{Faith and Secular Employment}

Corbin's work related to law and religion recalls Thomas Jefferson's assertion that there should be a wall of separation between Church and State. Thus, it is no surprise that clergy and lay librarians who see their work as a calling, but who are employed at public statesponsored schools, are aware of the limits to which personal religious convictions may be openly expressed in the course of their work. Donald G. Davis, Jr., and John Mark Tucker, who worked at the University of Texas and Purdue University respectively, shared their thoughts on the role of librarians who happen to be Christian and find themselves in just these sorts of settings. Drawing on a passage from Colossians $(3: 17,23-24)$ they point out that all work that Christians perform, even as laity in the secular world, is to be done as a ministry on behalf of Jesus (Davis Jr. and Tucker 2002, 42). That does not appear to mean that one may proselytize one's coworkers. Instead, they suggest that for Christian librarians, religiosity plays out in subtle ways. For instance, religious values may influence the quality and kind of relationships that are formed in the workplace in terms of one's 1) willingness to mentor others, 2) desire to establish a reputation of being approachable and trustworthy when others are seeking counsel or advice, 3) enthusiasm for celebrating the gifts of others, and finally 4) treatment of coworkers and patrons almost as though they are family to the extent that one advocates for their wellbeing and success (Davis Jr. and Tucker 2002, 43-44). They concede that many of these behaviors, while Christian in their orientation and motivation, are simply good professional practice (45). Presumably, then, a Christian librarian working in a secular setting might be indistinguishable from a caring colleague of any other faith or even a compassionate non-believer. 
Other thoughts that are germane to this discussion were shared fifteen years ago at the ATLA Annual Conference by our colleague, Beth Bidlack. She highlighted the fact that although many members of ATLA work in professional schools designed to train clergy, several are employed in colleges and universities that are secular. These two work environments can seem to be poles apart. In the course of trying to come to grips with differences that she herself experienced working at both Bangor Theological Seminary and the University of Chicago, she wrote, "Traditionally, a seminary focuses on the practice of religious traditions, whereas a university focuses on the academic study of religious traditions" (Bidlack 2006, 40). This key difference played out in various ways. For example, the nature of the material added to the respective school's collections differed considerably in that the former included devotional materials that were outside of the scope of the latter. In her comments at that meeting, Bidlack also suggested that comparing mission statements, the relative sizes of schools, and their levels of organizational complexity (number of campuses, number of professional schools, and so forth) provides an excellent framework for understanding why work experiences may vary considerably between private secular universities and theological schools (Bidlack 2006, 40-43). Bidlack concluded her excellent thinking on how differences between types of educational institutions impact library work in the area of religion with reflections on what it means to be a theological librarian (46). This is an excellent idea, and I will now follow in her footsteps as I bring my own presentation to a conclusion.

\title{
THE HEART OF THE MATTER: WHAT IS A THEOLOGICAL LIBRARIAN?
}

\author{
Anecdote 5: The Question \\ When I worked in United Methodist seminary libraries, it was an \\ honor, privilege, and significant responsibility to serve on hiring \\ committees. At the phone interview stage, I had a stock question \\ for library job candidates: "How do you think a theological library \\ differs from other academic libraries? Invariably they answered that \\ collection development in seminary libraries focused on acquiring \\ books on the topic of religion and that the library's patrons were \\ planning to become ministers. True enough. But somehow, this \\ answer always felt a little simplistic. For myself, a key difference
}


was that library work in the seminary context was undertaken in an environment where the holy was welcomed, embraced, and celebrated.

As we have already briefly mentioned in an earlier section above, many theological librarians conceive of their work as stemming from a ministry or calling. In fact, Bidlack herself described her work at Bangor Theological Seminary as a ministry. She noted, however, that her work as a religion bibliographer at the University of Chicago required subject knowledge, advanced degrees, and technical skills, but not necessarily the service-oriented approach to librarianship that many Atla librarians tend to highlight in their work-elements such as hospitality, ministry, and stewardship (Bidlack 2006, 46). Although she elected to bring a service-oriented approach to her work as a bibliographer, that did not seem to be a requirement of the job. As a result, Bidlack began to wonder whether a university librarian employed in a secular context, even if collecting works on religion, can truly be identified a theological librarian (46). She left the question unanswered, simply posing it for others to ponder.

If I were to offer an answer, I would say no. Although I was at one time a theological librarian, at this moment in my career I no longer am-even though my Ph.D. is in Bible, and I am undertaking this "theological" presentation here at Atla as part of my scholarly research. Rather, within the context of working at UWG, I would describe myself as a librarian who happens to be religious. In short, whether or not one is a theological librarian may change as one moves from institution to institution throughout one's working years. Fair warning: altering one's identity and self-perception so drastically may require a significant level of adjustment.

To flesh out what I mean by the distinctive roles, I propose that we use three separate designations for our work: theological librarian, religious librarian, and religion librarian. They are defined as follows:

\section{Theological Librarian:}

These librarians possess subject expertise or technical skills related to religion. Yet in addition to executing typical library tasks, they are permitted to openly engage in religious praxis, model values of the faith for others, and undertake theological reflection within the context of workday activities and research. They feel at home doing this formative work along with their regular library tasks. The work of the theological librarian typically takes place in an environment 
designed to promote and promulgate encounters with the holy at an institution that understands its mission as a response to a higher power. Although usually this would be a school of theology, it also might be a private, religious faith-based college/university or even a library outside of the academy, such as one located in a denomination's headquarters.

\section{Religious Librarian}

This is the Christian librarian described by Davis and Tucker but may also be a librarian of any religion or faith tradition. The religious librarian usually works in an environment where devotional acts and open religiosity are not appropriate, such as a secular private university, a public university, or a non-profit where the school may or may not offer a degree in religion or collect library resources in that subject. If tenured and possessing appropriate credentials, however, the religious librarian may research, write, and publish in the field of religion and theology. Furthermore, within the context of doing one's daily work, the religious librarian incorporates the values of his/her faith as a matter of private conscience to the extent possible.

\section{Religion Librarian:}

The religion librarian may be found in any type of institution, including a school of theology. He or she has subject expertise and technical skills in religion as appropriate for the position that he or she holds-perhaps as a religion bibliographer. Yet this librarian views his or her own work as a career or occupation without ascribing to it confessional or religious overtones or motivations. Further, interactions with others and work behaviors are likely rooted in basic human decency rather than faith convictions. To this end, the religion librarian who chooses to accept employment in a school of theology or a faith-based college or university may not feel at home taking part in forming students or participating in faith activities. That being said, they would not see the need to inhibit colleagues who do.

Whatever type of librarian you may be, at any point of time during your career, you enrich the work and connections we make here at Atla. I wish you well in wherever your career may take you, and if, like myself, you find yourself transitioning from the private sector to public tertiary education, and would like to reach out, I'd be happy to hear from you. 


\section{APPENDIX}

\section{CAREER MOVE ASSESSMENT TOOL}

5 is highest rating, most desirable in each category

Category 1: Basics \& Personal

This category would include things like salary expectations, move closer to family, quality of schools for children, special benefits, cost of living, how well skills and education match job requirements, sabbatical policy, research/travel/conference support etc.

Must-Haves

Evidence at Institution

Score 1-5

Example:

Short Commute

Map shows 27 minutes in traffic

1.

2

3.

4.

Category 2: Carnegie Considerations

Similarities to your current post. The higher the score, the more similar to your current position and, in theory, the easier the adjustment.

Characteristic

Score 1-5

Size

Degree levels offered (associates through doctorate)

Number of advanced degrees conferred

Length of program - 2 years, 4 years, other

Level of research

Setting (residential, commuter, online etc.)

Focus - arts, sciences, professional, special

Student characteristics - full time, part time, transfers

Other

Category 3: Other Qualities of Target Institution

Assign a higher score if the institution matches your preferences.

Characteristic 


\section{Score 1-5}

(5 is most preferred)

Conservative/Liberal

Prestigious/Humble

Selective Enrollment/Open Doors

Well-Funded/Financially Distressed

Rural/Suburban/Urban

Faith based/Historically Religious/Secular

Racial/Ethnic Serving

Safe (Clery Act Stats)

Other

Category 4: Overall Character of institution and Environment/Culture

To what extent do each of the following match your preferences for the workplace?

Keep in mind an individual department within the school may have its own unique subculture. In addition, changes in leadership or at the state capital (for public hchools) may change the culture and character of the school over time.

\section{Characteristic}

Score 1-5

Private, public, non-profit environment

Level of collegiality

Ability to be your genuine self, express your full identity (religious, gender, race, other)

Work ethic and pace of work matches your preferences Values match your preferences

Other

Category 5: Other Perks/Considerations

Characteristic

Score 1-5

Offers faculty status to librarians

Moving and/or housing allowances/loans

Other 


\section{Scoring}

Total the categories. Score possible is $118-140$ as written. Feel free, though, to add items to customize this for yourself. That would alter the score totals. The higher the score, in theory, the better the "fit".

Optional Weighting.

Pick the 2-3 "must-haves" and "characteristics" that are MOST important to you.

- If those characteristics/must-haves already have a high score, make them higher by adding an extra 20 points to those elements! (Each of those lines may now be as high as 25).

- If those characteristics/must-haves have a low score, subtract 26 points from that line. That means the lowest possible rating for those weighted lines would be -25 .

\section{Thoughts/Notes/Reactions}

Complete this assessment tool twice for each institution. The first time, complete it right after an interview or campus visit. Then give it a day or two and fill it out again to see if your impressions/comments/ reactions are the same.

\section{WORKS CITED}

Antell, Karen, and Susan E. Hahn. 2020. "Faculty Status: The Next Generation Employment Status Preferences among Millennial LIS Students and New Librarians at ARL Institutions.” The Journal of Academic Librarianship 46 no. 6: 1-9. doi:10.1016/j. acalib.2020.102250.

Association of Theological Schools in the United States and Canada. 2021. Data Tables 2020-2021. https://www.ats.edu/uploads/ resources/institutional-data/annual-data-tables/2020-2021\%20 Annual\%20Data\%20Tables.pdf

Association of Theological Schools in the United States and Canada. 2017. Data Tables 2016-2017. https://www.ats.edu/uploads/ resources/institutional-data/annual-data-tables/2016-2017annual-data-tables.pdf.

Bidlack, Beth. 2006. "Some Observations on Theological Librarianship in Seminary and University Contexts.” American Theological Library Association Summary of Proceedings 60: 38-48. 
Blumenfeld, Warren. 2006. "Christian Privilege and the Promotion of 'Secular' and Not-So 'Secular' Mainline Christianity in Public Schooling and in the Larger Society." Equity and Excellence in Education. 39, no.3: 195-210. https://doi. org/10.1080/10665680600788024.

Bowman, Nicholas A., and Cynthia Toms Smedley. 2013. "The Forgotten Minority: Examining Religious Affiliation and University Satisfaction.” Higher Education 65 (June): 745-760. https://doi. org/10.1007/s10734-012-9574-8.

Calhoun, Craig. 2011. "The Public Mission of the Research University.” In Knowledge Matters: The Public Mission of the Research University, edited by Diana Rhoten and Craig Calhoun, 1-33. New York: Columbia University Press.

Campbell, Kelly, and Andrew Keck. 2020. "Theological Librarianship as Career Path.” In The Theological Librarian's Handbook: Introduction to Theological Libraries, edited by Matina Ćurić, 17-24. Chicago: Books@ATLA Open Press.https://doi.org/10.31046/atlaopenpress.34.

The Carnegie Classification of Institutions of Higher Education. n.d. "Definitions and Methods." Accessed June 29, 2021. https://carnegieclassifications.iu.edu/definitions.php .

Clark, Christin, Mark Brimhall Vargas, Lewis Scholosser, and Craig Alimo. 2002. 'It's Not Just 'Secret Santa' in December: Addressing Educational and Workplace Climate Issues Linked to Christian Privilege.” Multicultural Education 1, no.2 (Winter): 52-57.

Corbin, Caroline Mala. 2017. "Government Employee Religion.” Arizona State Law Journal 49 (4): 1193-1256. Accessed September 1, 2021. https://arizonastatelawjournal.org/wp-content/ uploads/2018/02/Corbin_Pub.pdf.

David, Donald G., Jr., and John Mark Tucker. 2002. "The Master We Serve: The Call of the Christian Librarian to the Secular Workplace.” In Christian Librarianship: Essays on the Integration of Faith and Profession, edited by Gregory A. Smith, 40-47. Jefferson, NC: McFarland.

De Brey, Cristobal, Thomas D. Snyder, Anlan Zhang, Sally A. Dillow, National Center for Education Statistics (ED), and American 
Institutes for Research (AIR). 2021. "Digest of Education Statistics 2019. 55th Edition. NCES 2021-009.” National Center for Education Statistics, February. https://nces.ed.gov/pubs2021/2021009.pdf Edwards, Kristen T. 2015. "Perceptions of Power and Faith among Black Women Faculty: Re-thinking Institutional Diversity.” Innovative Higher Education 40, no. 3 (June): 263-278 https://doi. org/10.1007/s10755-014-9312-5.

Ellis, Carolyn, Tony E Adams, and Arthur P. Bochner. 2010. "Autoethnography: An Overview.” Forum Qualitative Sozialforschung / Forum: Qualitative Social Research, 12 (1). https://doi. org/10.17169/fqs-12.1.1589.

Fairchild, Ellen E., and Warrant J. Blumenfeld. 2006. “Traversing Boundaries: Dialogues on Christian Privilege, Religious Oppression, and Religious Pluralism among Believers and Non-Believers.” The College Student Affairs Journal 26, no. 2 (Spring): 177-185.

Fairchild, Ellen E. (2009) “Christian Privilege, History and Trends in US Religion.” New Directions in Student Services 125 (Spring): 5-11. https://doi.org/10.1002/ss.302.

Fox Garrity, Bonnie K. 2017. "What Is the Difference? Public Funding of For-Profit, Not-For-Profit, and Public Institutions.” In For-Profit Universities: The Shifting Landscape of Marketized Higher Education, edited by Tressie McMillan Cottom and William A. Darity, Jr., Springer International Publishing.

Hagerty, Barbara Bradley. 2010. "Christian Academics Cite Hostility on Campus: NPR.” All Things Considered. Aired August 3, 2010. https://www.npr.org/templates/story/story. php?storyId=128959747.

Harris, Jennifer. 2019. “Challenges of Nursing Faculty Retention.” The Midwest Quarterly. 60, no. 3 (Spring): 251-269.

Jones, Jeffrey M. 2021. "U.S. Church Membership Falls Below Majority for First Time.” Gallup. March 29, 2021. https://news.gallup. com/poll/341963/church-membership-falls-below-majority-firsttime.aspx.

Keck, Andrew J. 1996. "Information or Divine Access: Theological Librarianship within the Context of a Ministry" in The American 
Theological Library Association: Essays in Celebration of the First Fifty Years, edited by M. Patrick Graham, Valier R. Hotchkiss, and Kenneth E. Rowe, 172-182. Evanston, IL: American Theological Library Association.

Kelly, Brendan B. 2021. "Inaugural University Address” invitation sent to faculty at the University of West Georgia. July 21, 2021.

Leahy, Liz. 2021. "The Unique Contributions of the Theological Librarian in Campus-Wide Programs of Faith Integration.” Presented at Atla Annual (conference). June 16, 2021.

Lee, J. Steve. 2021. "The Persecution of Christians on Campus.” Is Christianity True? (blog). Accessed July 29, 2021. https://ischristianitytrue.wordpress.com/2021/03/31/the-persecution-of-christians-on-campus/.

Liftin, Duane. 2004. Conceiving the Christian College. Grand Rapids, MI: William B. Eerdmans.

McCormick Alexander C., and Zhao Chun-Mei. 2005. "Rethinking and Reframing the Carnegie Classification.” Change 37, no. 5: 50-57.

McMahan, Melody Layton. 2010. "Theological Librarianship: An Unapologetic Apology.” Theological Librarianship 3, no 1 (June):7-14. https://doi.org/10.31046/tl.v3i1.131.

Morris, Raymond, P. 1953/2006. "Theological Librarianship as a Ministry.” In A Broadening Conversation: Classic Readings in Theological Librarianship, edited by Melody Layton McMahon and David R. Stewart, 7-17. Lanham, MD: Scarecrow Press.

OECD. 2020. Education at a Glance 2020: OECD Indicators. Paris: OECD Publishing. https://doi.org/10.1787/69096873-en.

Peterson, Herman A. 2001. “Theological Librarianship as Ministry.” American Theological Library Association Summary of Proceedings 55: 231-50.

Rantung, Fanny H. 2014. "Factors Contributing to Faculty Satisfaction and Its Relationship to Faculty Retention in Tertiary Institutions." Human Behavior, Development and Society, 9 no. 1 (July): 47-57. https://so01.tci-thaijo.org/index.php/hbds/article/ view/173684. 
Rupp, Nicolas G., and A. Zeager. 2018. "Paid Parental Leave and Female Faculty Retention.” Eastern Economic Journal 44: 475-488.

Schröder, Stefan. 2017. "Humanist Organizations and Secularization in Germany." Religion \& Society in Central \& Eastern Europe 10, no. 1: 21-34. doi:10.20413/rascee.2017.10.1.21-34.

Schuman, Samuel. 2010. Seeing the Light: Religious Colleges in Twenty-First-Century America. Baltimore: Johns Hopkins University Press.

Scott, Whitney, Daisy Lemus, Greg Knotts, and Janet Oh. 2016. "Why Learner-Centered New Faculty Orientations Matter: Organizational Culture and Faculty Retention.” Journal of Faculty Development 30, no. 1: 15-22.

Shaffett, John E. 2013. "Theological Librarianship as Ministry.” American Theological Library Association Summary of Proceedings 67: 69-83.

Sheppard, Andy. (May 19, 2011). What is Unique about Southwestern College? Courier Traveler, https://www.ctnewsonline.com/ news/article_39d3b2f0-5df0-5be1-8df3-4018fofc2ddb.html.

United States Census Bureau. 2019. "Educational Attainment Table S1501” https://data.census.gov/cedsci/table?t=Educational\%20 Attainment\&g=0100000US.04000.001_0200000US1,2,3,4\&y=2019 \&tid=ACSST1Y2019.S1501.

Vryhof, Steven C. 2004. "Schools as Communities of Meaning." The Journal of Education 185, no. 2: 59-65.

White-Lewis, Damani K. 2020 "The Facade of Fit in Faculty Search Processes.” The Journal of Higher Education 91 no.6: 833-857. https://doi.org/10.1080/00221546.2020.1775058.

\section{ENDNOTES}

1 This number includes those designated as head librarians in member schools and also those identified as professional staff.

2 If the math is correct, assuming a 40-hour week, this represents an average reduction of 6 hours' worth of librarian labor per week in supporting each of the member schools' libraries. A deeper analysis of the data, including an analysis of the intervening years, is necessary to firmly establish any trends. 
3 It will be interesting to see if COVID-19 accelerates this downward trend, or temporarily reverses it, should the jobless seek out graduate schooling, including theological education.

4 Public schools are mentioned in passing (205), though not in the context of the category "control."

5 The 2018 data also revealed that there were 300 fouryear faith-based schools, one of which was for-profit and the remainder private. Together they enrolled 88,068 students. The CCIHE2018 spreadsheet may be downloaded from: https://carnegieclassifications.iu.edu/downloads/ CCIHE2018-SummaryTables.xlsx/.

6 Indirect funding from the government might take the form of student loans and Pell Grants as part of Title IV Aid.

7 I would like to thank J. A. Sheppard (who also published the piece referenced here under the name "Andy Sheppard") for being willing to expand on his work in a series of conversations with me during May 2021. Table 1 reflects many of his insights.

8 Although Harris studied Nursing faculty in particular, these concepts appear to be universal across faculty. A unique need amongst nurses, according to Harris, was the requirement of flexibility in timelines for promotion and tenure given additional responsibilities nursing faculty have related to their clinical duties.

9 Question \#35 on the survey did inquire about satisfaction with the moral values of the institution.

10 That is not to imply that the USA is a "Christian nation." Ellen Fairchild expresses concerns about that notion and stresses that the founding fathers intended a separation of Church/ State (Fairchild 2009, 6).

11 Bowman and Smedley are focused on the positive goods the multicultural model might have for student retention on campuses, though likely faculty and staff retention numbers might be impacted by the implementation of a similar model depending on the dominant workplace culture. 